\title{
KONSEKUENSI YURIDIS DARI KETIADAAN AKTA CERAI AKIBAT PERKAWINAN KEDUA ATAU LEBIH TERHADAP PEMBUKTIAN STATUS HARTA BAWAAN
}

\author{
Robby Pramono, Budi Santoso \& Hanif Nur Widhiyanti \\ Program Studi Magister Kenotariatan, Fakultas Hukum, Universitas Brawijaya \\ Jalan Abdul Muis 52-56A, Jakarta, 10160, \\ Email: sign_robby@yahoo.co.id
}

\begin{abstract}
The purpose of this paper is to analyze the juridical consequences of the withdrawal requirement of divorce certificate required by the Office of Religious Affairs as a requirement for divorced parties to resume marriage, in view of the proof of ownership status of loot. The type of research is normative conducted by examining the legal materials. The authority of the Office of Religious Affairs to enforce the requirements for the withdrawal of a divorce certificate and its decision for a divorced couple to re-establish a marriage has made it difficult to prove a marital status as a widower upon acquisition of property / property. It affects the absence of clarity and certainty whether the property belongs to the classification of luggage acquired after the occurrence of perceraiaan and before the second marriage takes place / more, or indeed the property is a treasure gono gini obtained from the previous marriage that has not been divided after the occurrence of perceraiaan. The Decision of the District Court of Surakarta Number 20/pdt.G/2013/PN. Ska is an example of the consequence of a conflict of law due to the absence of a deed of perceraiaan and its verdict, as evidence that guides the status of ownership of property owned by a person, determines those parties who have property rights with such property and are obliged to be asked for approval, when the property will be encumbered with a certain legal act, either transferred by way of sale, pledge or limited to lease.
\end{abstract}

Keywords: Divorce certificate, Marriage second/more, Ownership of loot.

\begin{abstract}
Abstrak
Tujuan penulisan ini untuk menganalisis konsekuensi yuridis dari ketentuan penarikan akta cerai yang diwajibkan oleh Kantor Urusan Agama sebagai persyaratan bagi pihak yang pernah bercerai untuk melangsungkan lagi perkawinan, ditinjau dari pembuktian status kepemilikan harta bawaan. Jenis penelitian bersifat normatif yang dilakukan dengan cara meneliti bahan-bahan hukum. Kewenangan KUA dalam memberlakukan persyaratan penarikan akta cerai berikut putusannya bagi pasangan yang pernah bercerai untuk melangsungkan kembali suatu perkawinan telah menyebabkan sulitnya dilakukan pembuktian atas status perkawinan seseorang sebagai duda/janda pada saat diperolehnya harta benda/harta kekayaan. Hal tersebut berdampak pada tidak adanya kepastian apakah harta benda tersebut masuk ke dalam klasifikasi harta bawaan yang diperoleh setelah terjadinya perceraiaan dan sebelum dilangsungkanya perkawinan yang kedua/lebih, atau memang harta benda tersebut merupakan harta gono gini yang diperoleh dari perkawinannya terdahulu yang belum terbagi setelah terjadinya perceraiaan. Putusan Pengadilan Negeri Surakarta Nomor 20/pdt.G/2013/PN.Ska adalah contoh dari timbulnya konsekuensi berupa konflik hukum oleh karena ketiadaan akta perceraiaan maupun putusannya, sebagai alat bukti yang menjadi dasar petunjuk mengenai status kepemilikan harta benda yang dimiliki seseorang, terutama dalam hal menentukan pihak-pihak yang memiliki keterkaitan hak dengan harta benda tersebut dan wajib untuk dimintai persetujuannya, ketika harta benda tersebut akan dibebani suatu perbuatan hukum tertentu, baik dialihkan dengan cara dijual, dijaminkan ataupun sebatas disewakan.
\end{abstract}

Kata kunci: Akta cerai, perkawinan kedua/lebih, harta bawaan. 


\section{Pendahuluan}

\subsection{Latar Belakang}

Perkawinan merupakan suatu ikatan lahir dan batin yang timbul antara seorang pria dengan wanita yang bertujuan untuk membentuk suatu keluarga. Penjelasan mengenai difinisi perkawinan sebagaimana Undang-Undang Nomor 1 Tahun 1974 Tentang Perkawinan (selanjutnya disebut UU Perkawinan) adalah:1 "Perkawinan adalah ikatan lahir batin antara seorang pria dan seorang wanita sebagai suami istri dengan tujuan membentuk keluarga atau rumah tangga yang bahagia dan kekal berdasarkan Ketuhanan Yang Maha Esa".

Tujuan perkawinan dari uraian difinisi diatas pada awalnya adalah untuk membentuk suatu kehidupan keluarga yang bahagia dan kekal namun pada kenyataannya tujuan tersebut tidak selalu berjalan sesuai dengan fungsi dari nilai-nilai dasar perkawinan itu sendiri. Permasalahan-permasalahan yang timbul dalam kehidupan perkawinan menyebabkan banyak diantara pasangan suami-istri yang lebih memilih mengakhiri perkawinannya ke dalam suatu perceraiaan.

Salah satu konsekuensi dari terjadinya perceraiaan adalah polemik terkait dengan pembagian atas harta/aset kekayaaan yang dimiliki/diperoleh oleh suami-istri selama perkawinan yang tentu saja secara hukum menjadi harta bersama (gono-gini), hal tersebut sebagaimana dijelaskan dalam UU Perkawinan yang berbunyi sebagai berikut:2
1. Harta benda yang diperoleh selama perkawinan adalah menjadi harta bersama;

2. Harta bawaan yang berasal dari masing-masing suami istri dan harta benda yang diperoleh masing-masing sebagai hadiah atau warisan, adalah menjadi dibawah penguasaan masingmasing sepanjang para pihak tidak menentukan lain.

Ketentuan diatas menegaskan bahwa harta benda yang diperoleh selama perkawinan merupakan harta bersama, percampuran harta tersebut terjadi apabila suami-istri tersebut tidak melaksanakan perkawinan dengan didasari oleh suatu Perjanjian Perkawinan/ Perjanjian Pisah Harta karena dengan tidak dibuatnya perjanjian perkawinan maka akan terjadi semua pembauran harta suamiistri. $^{3}$

Tidak semua pasangan yang bercerai menyelesaikan pembagian harta harta gono gininya di meja pengadilan melalui suatu penetapan/putusan Hakim, sehingga dengan demikian kedudukan harta masih memiliki status hukum yang belum jelas terkait pembagiannya. Ketiadaan putusan/penetapan mengenai pembagian harta gono gini dalam suatu perceraiaan, mengakibatkan perbuatan hukum terhadap harta, baik yang terdaftar atas nama salah satu pihak siapapun itu, tetap harus mendapatkan persetujuan dari mantan suami atau istrinya. Perbuatan hukum dimaksud tidak hanya perbuatan hukum menjual saja, melainkan termasuk menjaminkan atau menyewakan harta tersebut kepada pihak lain.

Pasal 1 Undang-Undang Nomor 1 Tahun 1974 Tentang Perkawinan

Pasal 35 Undang-Undang Nomor 1 Tahun 1974 Tentang Perkawinan

A.Damanhuri HR, Segi-segi Hukum Perjanjian Perkawinan Harta Bersama, Bandung:CV Mandar Maju 2007, hlm.3 
Permasalahan terhadap pembuktian kepemilikan harta kerap terjadi manakala pihak yang telah bercerai kembali melangsungkan perkawinan dengan pihak yang berbeda, permasalahan tersebut timbul ketika pihak lembaga pencatat perkawinan dalam hal ini Kantor Urusan Agama (selanjutnya disebut KUA) mengharuskan dan mewajibkan untuk menarik asli akta cerai berikut Putusan Cerai Pengadilan Agama (selanjutnya disebut Putusan) sebagai syarat melangsungkan lagi perkawinan yang sah secara hukum. Penarikan terhadap akta cerai berikut putusannya oleh KUA tentu saja berpotensi menimbulkan permasalahan terhadap pembuktian atas kepemilikan harta, baik pembuktian apakah harta tersebut memang menjadi kesatuan gono-gini dengan mantan suami/istri dan belum terpisahkan oleh suatu putusan gono-gini ataukah memang harta tersebut merupakan suatu harta bawaan yang diperoleh setelah terjadinya perceraiaan. Permasalahan pembuktian tersebut harus dihadapi pemilik harta dan sangat diperlukan pada saat harta tersebut akan dibebani suatu perbuatan hukum tertentu seperti dijual ataupun sebatas dijaminkan atau disewakan.

Persoalan pembuktian terhadap status harta akan menjadi polemik jika dilihat dari sisi yang besentuhan dengan kewenangan Notaris/PPAT ataupun pejabat lain yang setara, yang tentunya lebih bersifat mengantisipasi segala bentuk kemungkinan bilamana harta tersebut pada kenyataannya memang merupakan harta yang diperoleh ketika status perkawinan pemilik belum terputus karena perceraiaan dengan mantan suami atau istrinya sehingga apapun perbuatan hukum terhadap harta benda tersebut wajib mendapatkan persetujuan dari mantan suami atau istrinya.

Konflik hukum yang timbul dari ketiadaan akta cerai berikut putusannya sebagai petunjuk dasar atas status kepemilikan harta adalah sebagaimana kasus pembatalan oleh Pengadilan Negeri Surakarta terhadap akta jual beli atas tanah dan/atau bangunan yang dibuat dihadapan Sunarto, Sarjana Hukum, selaku Notaris/PPAT Kota Surakarta. ${ }^{4}$ Pembatalan tersebut terjadi tidak lain oleh karena jual beli yang dilaksanakan para pihak tidak melibatkan mantan istri dari pihak penjual, yang tentu saja jual beli tersebut berpotensi merugikan kepentingan dan hak-hak mantan istri pihak penjual. Pihak Notaris/PPAT menyatakan pada saat transaksi jual beli berlangsung penjual hanya menghadirkan istri keduanya yang namanya sebagaimana tertera dalam Kartu Keluarga sebagai satu-satunya dasar acuan, tanpa mengetahui bahwa pihak penjual memiliki mantan istri yang perlu dimintai persetujuannya. Ketidakikutsertaan mantan istri pihak penjual untuk memberikan persetujuan menyebabkan terjadinya suatu bentuk konflik hukum yang berujung pada dibatalkannya akta jual beli oleh pengadilan Negeri Surakarta. Konsep dasar dari kasus tersebut adalah dapat dibuktikannya dihadapan hakim pengadilan bahwa harta yang perjualbelikan tersebut merupakan harta gono gini yang diperoleh selama perkawinan sehingga perbuatan hukum dalam hal mengalihkan harta tersebut seharusnya wajib terlebih dahulu mendapatkan persetujuan dari mantan istri penjual. Ketiadaan persetujuan tersebut membuat hakim menganggap bahwa tindakan hukum para pihak sebagaimana tertuang dalam akta jual beli tidak lain

4 Putusan Pengadilan Negeri Surakarta Nomor 20/pdt.G/2013/PN.Ska 
merupakan suatu bentuk perbuatan melawan hukum. Hal tersebut tentu saja mengacu pada suatu titik pembuktian yang merujuk beban pembuktian berdasar atas prinsip pembuktian yang mengarah pada teori hukum subyektif berdasarkan atas ketentuan pasal 1865 KUHPerdata yang mengatakan bahwa siapa yang mengemukakan atau mempunyai suatu hak tanpa adanya hak orang lain maka harus membuktikannya. ${ }^{5}$

Kondisi dan potensi konflik sebagaimana contoh kasus diatas tentunya timbul oleh karena ketiadaan akta cerai sebagai dasar acuan dalam pembuktian atas status perkawinan seseorang pada saat diperolehnya harta kekayaan, yang mana hal tersebut berujung pada sulitnya bagi pihak Notaris/PPAT untuk dapat menentukan pihak-pihak yang wajib dihadirkan untuk dimintai persetujuannya terkait dengan perbuatan hukum tertentu yang akan dilakukan oleh para pihak. Belum terdapatnya solusi konkret dari KUA terhadap permasalahan tersebut menyebabkan rentannya terjadi pelanggaran hukum yang dapat berujung pada timbulnya permasalahan hukum dan tidak lain disebabkan oleh karena sulitnya untuk dapat membuktikan status hukum atas perkawinan seseorang.

Atas dasar uraiaan latar belakang di atas, maka dapat dicermati serta disimpulkan bahwa inti dari pokok permasalahan yang akan menjadi suatu bentuk rumusan masalah sebagai dasar pembahasan adalah: (1) Adanya ketentuan penarikan akta cerai yang diwajibkan oleh Kantor Urusan Agama sebagai persyaratan bagi pihak yang pernah bercerai untuk melangsungkan lagi suatu perkawinan; (2) Timbulnya konsekuensi dari penarikan akta cerai tersebut yang akan berdampak pada sulitnya pembuktian terhadap status kepemilikan bawaan maupun harta gono gini.

Berdasarkan latar belakang di atas, maka terdapat isu hukum yang akan dibahas dalam tulisan ini, yaitu mengenai konsekuensi yuridis dari adanya ketentuan penarikan akta cerai yang diwajibkan oleh Kantor Urusan Agama sebagai persyaratan bagi pihak yang pernah bercerai untuk melangsungkan lagi perkawinan jika ditinjau dari pembuktian status kepemilikan harta bawaan.

\section{Tinjauaan Pustaka}

\subsection{Tinjauan Umum Mengenai Perkawinan Dan}

\section{Perceraiaan}

a) Pengertian Perkawinan

Pengertian Perkawinan menurut UU Perkawinan adalah Ikatan lahir batin diantara seorang pria dan seorang wanita sebagai suami-istri yang bertujuan membentuk keluarga atau rumahtangga yang bahagia dan kekal berdasarkan Ketuhanan Yang Maha Esa. ${ }^{6}$ Jadi perkawinan tersebut adalah ikatan seorang pria dan wanita berarti perkawinan sama dengan perikatan; ${ }^{7}$

b) Syarat Sah Perkawinan

Syarat sah dalam perkawinan adalah sebagai berikut: ${ }^{8}$

1) Perkawinan adalah sah apabila dilakukan menurut hukum masingmasing agama serta kepercayaannya itu;

2) Tiap-tiap perkawinan dicatat menurut peraturan perundangan yang berlaku.

\footnotetext{
M. Natsir Asnawi, Hukum Pembuktian Perkara Perdata Di Indonesia, Yogyakarta: UII Press, 2013, hlm.122

Pasal 1 Undang-Undang Nomor 1 Tahun 1974 Tentang Perkawinan

Hilman Hadikusuma, Hukum Perkawinan Indonesia, Bandung:Mandar Maju 2002, hlm.6

Pasal 7 Undang-Undang Nomor 1 Tahun 1974 Tentang Perkawinan
} 
Syarat perkawinan sebagaimana ketentuan diatas menggambarkan bahwa perkawinan yang sah menurut perkawinan nasional adalah perkawinan yang dilaksanakan menurut tata-tertib aturan hukum yang berlaku dalam agamanya masing-masing. Kata hukum masing-masing agamanya berarti hukum dari salah satu agamanya itu masing-masing yaitu agama yang dianut oleh kedua mempelai atau keluarganya. ${ }^{9}$ Selain itu perkawinan juga wajib dilakukan pencatatannya. Fungsi Pencatatan Perkawinan adalah: ${ }^{10}$

1) Untuk memenuhi administrasi Negara dan sebagai bukti yang kuat dalam menentukan kedudukan hukum seseorang agar terwujud adanya suatu kepastian hukum ketertiban hukum dan perlindungan hukum terhadap perkawinan tersebut;

2) Akibat hukum dari suatu perkawinan yang tidak dicatatkan menurut UU Perkawinan adalah meskipun secara agama atau adat istiadat perkawinan tersebut sah namun dimata hukum perkawinan tersebut tidak sah dan tidak memiliki kekuatan hukum.

Berdasarkan Peraturan Pemerintah Nomor

9 Tahun 1975 sebagai peraturan pelaksana UU Perkawinan, dalam pencatatan suatu perkawinan, memiliki syarat sebagai berikut:

1) Pegawai Pencatat yang menerima pemberitahuan suatu kehendak melangsungkan perkawinan, meneliti apakah terhadap syaratsyarat suatu perkawinan telah terpenuhi dan apakah tidak terdapat suatu halangan terhadap perkawinan menurut Undang-undang;
2) Selain penelitian terhadap hal-hal sebagaimana dimaksud dalam ayat (a) Pegawai Pencatat meneliti pula:

a) Kutipan akta kelahiran para calon mempelai. Dalam hal tidak adanya suatu akta kelahiran atau surat kenal lahir maka dapat dipergunakan surat keterangan yang isinya menyatakan umur dan asal-usul para calon mempelai yang dibuat oleh Kepala Desa atau yang setingkat dengan itu;

b) Keterangan mengenai nama, agama serta kepercayaan, pekerjaan dan tempat tinggal dari orang tua calon mempelai;

c) Izin tertulis/izin dari Pengadilan sebagaimana dimaksud dalam pasal 6 ayat (2), (3), (4) dan (5) Undang-undang serta apabila salah seorang dari calon mempelai ataupun keduanya ternyata belum mencapai umur 21 tahun;

d) Izin dari Pengadilan sebagaimana dimaksud dalam Pasal 4 Undang-undang; apabila calon mempelai adalah seorang suami yang masih mempunya istri;

e) Dispensasi dari Pengadilan/Pejabat sebagaimana dimaksud dalam Pasal 7 ayat (2) Undang-undang;

f) Surat kematian istri atau suami terdahulu atau dalam hal telah terjadi perceraian dilampirkan surat keterangan perceraian, bagi perkawinan untuk kedua kalinya atau lebih;

9 Hilman Hadikusuma, Op.Cit. hIm. 25

10 Anonim "Fungsi Pencatatan Perkawinan" https://www.researchgate.net/publication/ 42323389 Fungsi PencatatanPerkawinan MenurutUndang-Undang Nomor 1 Tahun 1974 studi kasus pengadilan agama Medan, diakses pada tanggal 30 Januari 2018 
g) Izin tertulis pejabat yang ditunjuk Menteri HANKAM/PANGAB, jika salah seorang dari calon mempelai atau keduanya merupakan anggota dari Angkatan Bersenjata;

h) Surat kuasa otentik atau dibawah tangan yang telah disahkan Pegawai Pencatat, apabila salah seorang dari calon mempelai ataupun keduanya tidak hadir sendiri karena sesuatu alasan tertentu yang penting, sehingga mewakilkan kepada orang lain.

i) Pengertian Perceraiaan. Perceraian adalah terputusnya suatu hubungan perkawinan yang sah di depan hakim pengadilan yang didasarkan ketentuan dan syarat yang telah ditentukan undang-undang. Oleh sebab itu perlu dipahami terhadap segala bentuk peraturan mengenai perceraian itu sendiri, berikut sebab akibat yang mungkin timbul setelah hubungan perkawinan antara suami istri telah putus. Kemudian yang tidak kalah pentingnya adalah apakah alasan yang mendasari putusnya suatu perkawinan serta penyebab terjadinya perceraian. ${ }^{11}$

j) Penyebab Perceraiaan Perceraian dapat terjadi karena alasan atau alasan-alasan:

1) Salah satu pihak telah berbuat zina atau menjadi pemabok, pemadat dan penjudi atau lain sebagainya yang sulit disembuhkan;

2) Salah satu pihak meninggalkan pihak lain selama kurun waktu 2 (dua) tahun secara berturut-turut dan tanpa adanya suatu izin pihak lain serta tanpa disertai alasan yang sah atau karena hal-hal lain diluar kemampuannya;
3) Salah satu pihak dijatuhi atau mendapat sanksi hukuman penjara selama 5 (lima) tahun ataupun hukuman yang lebih berat setelah berlangsungnya perkawinan;

4) Salah satu pihak telah melakukan kekejaman ataupun penganiayaan yang membahayakan pihak yang lain;

5) Salah satu pihak mendapatkan cacat badan atau suatu penyakit yang berakibat tidak dapat menjalankan tugas dan kewajibannya sebagai suami/istri;

6) Diantara suami dan isteri terjadi terusmenerus perselisihan dan pertengkaran serta tidak ada harapan lagi akan hidup rukun lagi dalam rumah tangga.

k) Lembaga Peradilan Terkait Penanganan Perkara Perceraiaan. Perceraian hanya dapat dilakukan dihadapan Sidang Pengadilan, setelah Pengadilan berusaha dan tidak berhasil mendamaikan kedua belah pihak. Ketentuan tersebut membuktikan bahwa Gugatan perceraian hanya dapat diajukan di pengadilan, maka dan oleh karena itu lembaga peradilan yang berwenang menangani permasalahan terkait perceraiaan adalah:

1) Pengadilan Agama Pengadilan Agama adalah jenis pengadilan yang dikhususkan untuk yang beragama Islam. Artinya pengadilan agama hanya menangani sengketa perkawinan dikalangan orang-orang yang beragama Islam. ${ }^{12}$ Pengadilan Agama mulai berlaku terhitung sejak tanggal 29 Desember 1989, sejak diberlakukannya 
Undang-Undang Nomor 7 Tahun 1989 Tentang Peradilan Agama. Pengadilan Agama berwenang dan bertugas untuk memeriksa, memutus, dan menyelesaikan perkara-perkara ditingkat pertama diantara orang-orang yang beragama Islam di bidang:
a. perkawinan;
b. kewarisan dan wasiat maupun hibah, yang dilakukan berdasarkan hukum Islam;

c. wakaf dan shadaqah.

2) Pengadilan Negara. Pengadilan Negara adalah pengadilan yang hanya bertugas memeriksa gugatan perceraiaan dari mereka yang melangsungkan suatu perkawinan menurut keyakinan/agama Kristen/Katolik, Hindu/Budha atau lainnya yang tidak menganut agama Islam. ${ }^{13}$

\subsection{Tinjauan Umum Lembaga Pencatat Perkawinan Dan Perceraiaan}

Ketentuan pencatatan mengenai lembaga pencatat perkawinan dan perceraiaan diatur dalam PP Nomor 9 Tahun 1975 dengan ketentuan sebagai berikut:

\section{a. Kantor Urusan Agama}

Kantor Urusan Agama/Pegawai Pencatat Nikah adalah instansi yang diangkat oleh Menteri Agama dan berwenang melakukan pencatatan perkawinan dan perceraiaan menurut agama Islam, sebagaimana diatur dalam UndangUndang Nomor 32 Tahun 1954, tentang pencatatan terkait Nikah, Talak dan Rujuk. ${ }^{14}$ Bagi pemeluk agama Islam yang ingin melangsungkan perkawinan juga terlebih dahulu harus melalui segala bentuk prosedur awal dari perkawinan itu sendiri yaitu antara lain:

i. Memberitahukan keinginannya tersebut kepada pegawai pencatat perkawinan ditempat salah satu dari kedua pihak. Pemberitahuan dilakukan baik lisan atau tertulis, oleh calon mempelai atau oleh kedua orangtua atau walinya.

ii. Pemberitahuan tersebut memuat data identitas diri seperti antara lain Nama, umur, agama/kepercayaan, pekerjaan, tempat kediaman kedua calon mempelai dan apabila salah seorang atau keduanya sudah pernah kawin maka disebutkan juga nama istri atau suaminya terdahulu.

iii. Pemberitahuan terhadap perkawinan dilakukan sekurang-kurangnya dalam 10 (sepuluh) hari kerja sebelum perkawinan dilangsungkan, kecuali karena suatu alasan yang penting pemberitahuan perkawinan dapat dilakukan kurang dari 10 (sepuluh) hari dengan persetujuan Camat atas nama Bupati/Kepala Daerah setempat. Setelah prosedur pengumuman dan persyaratan telah dilengkapi serta setelah dilangsungkannya perkawinan dihadapan pegawai pencatat, saksi dan dihadapan wali, maka kedua mempelai menandatangani akta perkawinan yang disiapkan oleh pihak pegawai pencatat berdasarkan ketentuan yang berlaku dan juga ditandatangai oleh - 
wali nikah atau yang mewakilinya. Dengan ditandatanganinya akta perkawinan tersebut maka perkawinan itu telah tercatat dan resmi. Kantor Catatan Sipil.

iv. Bagi pemeluk agama selain Islam yang ingin melangsungkan perkawinan juga memiliki prosedur awal yang sama dengan pelaksanaan perkawinan secara Islam, hanya saja perkawinan yang dilakukan selain dari agama Islam terhadap penerbitan akta perkawinan tidak turut ditandatangani oleh wali nikah atau yang mewakilinya.

Dalam hal terjadinya perceraiaan maka perceraian tersebut benar-benar terjadi dengan segala akibatnya setelah dilakukannya pendaftaran terhadap Putusan Cerai Hakim Pengadilan Negeri pada Kantor Catatan Sipil yang beromisili pada saat perceraiaan terjadi untuk selanjutnya diterbitkan akta cerai. Panitera Pengadilan sebagaimana dimaksud berkewajiban mengirimkan salinan putusan pengadilan mengenai perceraian kepada Instansi Pelaksana atau UPTD Instansi Pelaksana tempat pencatatan peristiwa perkawinan jika domisili pengadilan yang memutus perceraiaan berbeda dengan domisili pegawai pencatat dimana perkawinan dahulu dicatatkan. Berbeda terhadap putusnya suatu perkawinan yang beragama Islam yang mana dalam hal terjadinya perceraiaan, kepastian putusnya cerai terhitung sejak jatuh putusan hakim Pengadilan Agama yang telah memiliki putusan tetap jadi bukan pada saat dilakukannya pendaftaran pencatatan terhadap putusan cerai pada Kantor Pencatatan Nikah.

Dihadapan pegawai pencatat, saksi dan dihadapan wali, maka kedua mempelai menandatangani akta perkawinan yang disiapkan oleh pihak pegawai pencatat berdasarkan ketentuan yang berlaku dan juga ditandatangani oleh saksi dan pegawai pencatat serta oleh wali nikah atau yang mewakilinya. Dengan ditandatanganinya akta perkawinan tersebut maka perkawinan itu telah tercatat dan resmi.

\section{b. Kantor Catatan Sipil}

Bagi pemeluk agama selain Islam yang ingin melangsungkan perkawinan juga memiliki prosedur awal yang sama dengan pelaksanaan perkawinan secara Islam, hanya saja perkawinan yang dilakukan selain dari agama Islam terhadap penerbitan akta perkawinan tidak turut ditandatangani oleh wali nikah atau yang mewakilinya.

Dalam hal terjadinya perceraiaan maka perceraian tersebut benar-benar terjadi dengan segala akibatnya setelah dilakukannya pendaftaran terhadap Putusan Cerai Hakim Pengadilan Negeri pada Kantor Catatan Sipil yang beromisili pada saat perceraiaan terjadi untuk selanjutnya diterbitkan akta cerai. Panitera Pengadilan sebagaimana dimaksud berkewajiban mengirimkan salinan putusan pengadilan mengenai perceraian kepada Instansi Pelaksana atau UPTD Instansi Pelaksana tempat pencatatan peristiwa perkawinan jika domisili pengadilan yang memutus perceraiaan berbeda dengan domisili pegawai pencatat dimana perkawinan dahulu dicatatkan. Berbeda terhadap putusnya suatu perkawinan yang beragama Islam yang mana dalam hal terjadinya perceraiaan, kepastian putusnya cerai terhitung sejak jatuh putusan hakim Pengadilan Agama yang telah memiliki - 
putusan tetap jadi bukan pada saat dilakukannya pendaftaran pencatatan terhadap putusan cerai pada Kantor Pencatatan Nikah.

\subsection{Tinjauan Umum Harta Benda Dalam Perkawinan}

Menurut UU Perkawinan harta benda perkawinan dibagi menjadi dua golongan, yaitu harta bersama atau disebut dengan harta gono gini dan harta bawaan atau harta asal.

1. Harta Bersama/Gono Gini

Harta gono-gini merupakan suatu bentuk harta bersama yang diperoleh selama berlangsungnya perkawinan. Hal tersebut didasarkan pada ketentuan UU Perkawinan yang menyatakan bahwa harta benda yang diperoleh selama perkawinan adalah harta bersama. Artinya harta bersama merupakan harta yang terbentuk sejak terjadinya perkawinan hingga perkawinan itu terputus. ${ }^{15}$

2. Harta Bawaan/Harta Asal

Harta bawaan sendiri dapat dipahami merupakan suatu harta benda yang dimiliki oleh masing-masing suami dan istri yang diperoleh sebelum terjadinya suatu ikatan perkawinan atau yang diperoleh sebagai bentuk warisan dan hadiah. Hal tersebut mengacu pada UU Perkawinan pasal 35 disebutkan bahwa harta bawaan masing-masing suami dan istri serta harta benda yang diperoleh masing-masing sebagai hadiah atau warisan, adalah dibawah penguasaan masing-masing sepanjang para pihak tidak menentukan lain. Atas dasar ketentuan tersebut dan sebagaimana diatur dalam UU Perkawinan pasal 36 ayat 2 dapat dimaknai bahwa harta bawaan bukanlah termasuk dalam artian harta gono gini sehingga untuk itu suami atau istri berhak untuk dapat mempergunakan harta bawaannya masingmasing tersebut dan juga dapat melakukan suatu bentuk perbuatan hukum terhadapnya.

\section{Metode Penelitian}

Metode yang digunakan adalah hukum normatif atau disebut juga metode penelitian kepustakaan yaitu suatu metode penelitian yang dilakukan dengan cara meneliti bahan-bahan pustaka yang ada dan bertujuan menemukan solusi terhadap permasalahan hukum yang ada dengan mengacu pada suatu bentuk peraturan perundangundangan yang ada maupun atas sumber-sumber hukum lain yang saling berkaitan dengan tujuan untuk mendapatkan suatu bentuk norma hukum yang sarat nilai guna tercapai dan terpenuhinya unsurunsur kepastian hukum yang dibutuhkan. Teknik analisis data dengan cara deduktif yaitu menjelaskan suatu hal yang bersifat umum kemudian menariknya menjadi kesimpulan yang lebih khusus. Analisis dilakukan dengan melakukan telaah terhadap kasus-kasus yang berkaitan dengan isu yang dihadapi dan dibahas.

\section{Pembahasan}

Di dalam ketentuan UU Perkawinan telah disebutkan dan dijelaskan perbedaan terkait kedudukan harta benda dalam perkawinan yaitu antara lain: (1) Harta benda yang diperoleh dalam perkawinan adalah menjadi harta bersama; (2) Mengenai harta bawaan dari masing-masing suami dan isteri dan harta benda yang diperoleh masing-

15 Anonim "Pembagian harta gono gini dalam perceraiaan" https://kantorpengacara.co/prosedur-pembagian-harta-gono-gini-dalamperceraian / diakses pada 01 Februari 2018 
masing sebagai hadiah atau warisan, adalah di bawah penguasaan masing-masing sepanjang para pihak tidak menentukan lain.

Ketentuan tersebut menjelaskan mengenai kedudukan harta benda dalam perkawinan, yang mana kedudukan dan posisi harta benda sangat berpengaruh atas perbuatan hukum terhadap harta benda itu sendiri, hal ini sebagaimana yang juga telah ditentukan dalam UU Perkawinan yaitu: (a) Mengenai harta bersama suami atau isteri dapat bertindak atas persetujuan kedua belah pihak; (b) Mengenai harta bawaan masing-masing, suami isteri mempunyai hak sepenuhnya untuk melakukan perbuatan hukum mengenai harta bendanya.

Berdasarkan ketentuan pasal 36 UU Perkawinan bahwa setiap harta benda yang diperoleh dalam perkawinan harus mendapatkan persetujuan dari suami istri sedangkan terhadap harta bawaan maka masing-masing pihak dapat bertindak sendiri atas perbuatan hukum yang dilakukannya terhadap harta bendanya. Harta bawaan dimaksud adalah termasuk harta yang diperoleh dan dibawa masing-masing suami istri kedalam ikatan perkawinan dari jerih payahnya sendiri sebelum atau setelah perkawinan. ${ }^{16}$

Harta kekayaan dalam perkawinan sering disebut dengan Istilah "gono-gini" merupakan sebuah istilah hukum yang sudah populer di masyarakat. Dalam Kamus Besar Bahasa Indonesia edisi Tahun 2001 halaman 330, istilah yang digunakan adalah "gona-gini", yang secara hukum artinya, "Harta yang berhasil dikumpulkan selama berumah tangga sehingga menjadi hak berdua suami dan istri". Kemudian berdasarkan Pasal 1 huruf f Instruksi Presiden (Inpres) Nomor 1 Tahun
1991 tentang Kompilasi Hukum Islam yang menyatakan "harta kekayaan dalam perkawinan (harta bersama) yaitu harta yang diperoleh baik sendiri-sendiri atau bersama suami-istri selama dalam ikatan perkawinan, tanpa mempersoalkan terdaftar atas nama siapapun".

Dari apa yang telah diuraikan diatas tentunya dapat diambil suatu kesimpulan mendasar yang menjadi pembeda dalam memahami konsep harta gono gini dengan harta bawaan. Perbedaan tersebut tidak hanya terletak pada cara perolehan atas harta benda tersebut atau status perkawinan seseorang pada saat harta tersebut didapat, tetapi perbedaan tersebut juga terdapat dalam hal melihat kewenangan seseorang terhadap harta benda yang dimilikinya, apakah kewenangan tersebut bersifat absolute atau bersifat relative. Perbedaan kewenangan tersebut harus dapat dibuktikan oleh suatu pembuktian karena jika didasarkan oleh pasal 1865 KUHPerdata yang mengatur tentang pembuktian, disebutkan bahwa setiap orang yang mengendalikan bahwa ia mempunyai sesuatu hak, atau, guna meneguhkan adanya haknya sendiri ataupun membantah adanya hak dari orang lain, menunjuk pada adanya suatu peristiwa, maka diwajibkan untuk membuktikan adanya hak atau peristiwa tersebut. Artinya ada atau tidaknya hak orang lain didalam kepemilikan suatu harta benda maka haruslah dapat dibuktikan kebenarannya.

Dalam memahami konsep status perkawinan maka tidak dapat dilepaskan dari buktibukti yang melekat pada diri seseorang terkait status perkawinan yang dimilikinya. Misalkan seseorang mengaku belum pernah menikah maka status tersebut hanya dapat dibuktikan dengan identitas -

16 Hilman Hadikusuma, Op.Cit, hlm. 114 
Kartu Tanda Penduduk atau Kartu Keluarga yang menegaskan hal tersebut, begitu juga jika seseorang mengaku telah berstatus menikah maka harus dibuktikan dengan adanya akta perkawinan, begitu pula apabila seseorang mengaku berstatus sebagai duda atau janda maka harus dapat dibuktikan dari adanya suatu akta perceraiaan apabila bercerai atau akta kematian apabila terjadi kematian pada pasangan kawinnya.

Pembuktian berasal dari kata bukti yang berarti keterangan nyata atau sesuatu yang menyatakan kebenaran suatu peristiwa. ${ }^{17}$ Dalam konteks hukum acara pembuktian dipahami sebagai bentuk alat bukti maupun hal-hal yang dapat dijadikan sebagai alat bukti, yang dihadirkan di muka persidangan pengadilan oleh para pihak yang berperkara, berupa kesaksian, rekaman, dokumendokumen, objek fisik tertentu dan sebagainya yang bertujuan untuk meyakinkan pengadilan atau juri bahwa dalil yang mereka kemukakan adalah benar. ${ }^{18}$

a. Kedudukan Akta Cerai sebagai alat bukti terhadap status kepemilikan harta benda

Di dalam pasal 1 ayat 17 UU Nomor 24 Tahun 2013 Tentang Administrasi Kependudukan (selanjutnya disebut UU Kependudukan) telah diuraikan prihal peristiwa-peristiwa apa saja yang dianggap sebagai kejadian penting yang dialami seseorang. Akta Cerai merupakan salah satu produk catatan sipil yang isinya mengurai tentang terjadinya suatu peristiwa penting bernama perceraiaan. Oleh karena itu kepemilikan terhadap akta cerai masuk kedalam konsep data perorangan sebagai salah satu terbentuknya data kependudukan. Fungsi dari data perorangan sebagai bagian dari data kependudukan adalah menjelaskan prihal jati diri seseorang, yang mana salah satunya adalah prihal status perkawinan orang tersebut. Artinya akta cerai dapat dipersamakan sebagai bukti identitas yang menunjukan jati diri seseorang terkait dengan status perkawinanya sebagai duda/janda.

Dilangsungkannya perkawinan kembali bagi pihak-pihak yang pernah bercerai tentunya akan mengubah status perkawinan mereka yang sebelumnya adalah sebagai duda/janda sehingga untuk selanjutnya menjadi berstatus menikah. Namun perubahan atas status perkawinan tersebut tetap tidak akan pernah dapat menghapus status perkawinan sebagai duda/janda yang pernah melekat pada diri seseorang, karena seperti yang diuraikan diatas bahwa perceraiaan merupakan suatu peristiwa penting yang dialami seseorang, sehingga status yang dimbulkan oleh peristiwa yang pernah dialami tersebut tentunya tidak serta merta dapat dihapus oleh suatu peristiwa lainnya yang disebut perkawinan.

Selain dari tidak akan terhapusnya citra/image sebagai duda/janda yang pernah melakat pada diri seseorang, ternyata terdapat beberapa hal yang tentunya juga tidak akan terhapus hanya oleh karena pihak-pihak yang pernah bercerai memutuskan untuk kemudian menikah lagi. Hal-hal tersebut antara lain terkait dengan status anak dan status harta benda. Dalam persoalan kepemilikan harta benda jika mengacu pada pasal 35 UU Nomor 1 Tahun 1974 maka tidak akan pernah dapat dianggap bahwa seluruh harta benda yang ada termasuk di dalamnya harta yang diperoleh sebelum berlangsungnya perkawinan -

17 Tim Penyusun, Kamus Besar Bahasa Indonesia, Edisi Kedua, Jakarta: Balai Pustaka, 1999, hlm.151

18 M.Natsir Asnawi. Op.Cit.hlm.3 
yang kedua/lebih adalah merupakan/akan menjadi kesatuan harta gono gini dengan pihak-pihak yang terikat dalam perkawinan kedua/lebih. Hal tersebut tidak lain dikarenakan harta benda tersebut bisa jadi merupakan harta bawaan atau bahkan merupakan harta kesatuan gono-gini dengan mantan istri/suaminya terdahulu yang belum terbagi. Konteks dapat dibuktikannya kapan dan bagaimana diperolehnya harta tersebutlah yang paling menentukan status harta benda tersebut.

Keinginan bagi para pihak yang pernah bercerai untuk melangsungkan kembali suatu perkawinan adalah merupakan suatu bentuk hak asasi dan tentunya merupakan perbuatan yang legal dan memang diperbolehkan serta jelas dasar hukumnya jika mengacu pada hukum positif yang berlaku di Indonesia. Namun keinginan tersebut tentunya dapat terlaksana apabila para pihak tunduk pada ketentuan dan prosedur serta persyaratan yang diberlakukan oleh lembaga pencatat perkawinan, jika memang perkawinan tersebut ingin dilaksanakan dan tercatat serta mendapat pengakuan sebagaimana ketentuan perundangan yang berlaku.

Penarikan akta cerai berikut putusannya sebagai bentuk persyaratan terhadap dilangsungkannya perkawinan bagi pihak yang pernah bercerai adalah merupakan prosedur wajib yang diberlakukan oleh KUA. ${ }^{19}$ Namun penarikan tersebut berdampak pada ketiadaan suatu bukti yang dapat menjelaskan peristiwa penting berupa perceraiaan yang memang pernah dialami seseorang. Padahal fungsi dari diterbitkannya akta cerai adalah bertujuan untuk memberikan keabsahan identitas dan kepastian hukum, perlindungan status hak sipil penduduk dan mendapatkan data mutktahir benar dan lengkap.

Status perkawinan memang memiliki hubungan keterikatan dan keterkaitan dengan berbagai hal salah satunya adalah terhadap harta benda. Keterikatan dan keterkaitan tersebut tidak lain adalah dalam hal melihat bagaimana status kepemilikan atas harta benda itu sendiri apabila dihubungkan dengan status perkawinan seseorang pada saat diperolehnya harta tersebut. Sehingga dapat disimpulkan apakah harta benda benda tersebut merupakan harta benda gono gini atau merupakan harta bawaan. Ketiadaan akta cerai yang berfungsi sebagai bukti keabsahan identitas yang sebenarnya bertujuan untuk memberikan kepastian hukum terkait status perkawinan seseorang telah menyebabkan sulitnya untuk mendapatkan bukti petunjuk terkait kedudukan dan status kepemilikan harta benda jika ditunjau dari status perkawinan seseorang pada saat perolehan atas harta tersebut.

Kedudukan terhadap suatu harta benda apakah masuk kedalam klasifikasi harta gono-gini atau harta bawaan memang sangat ditentukan oleh bagaimana dapat dibuktikannya asal-usul harta benda tersebut. Pembuktian tersebut harus merujuk dan didasarkan pada alat bukti yang memang dapat dijadikan sebagai bahan acuan yang memenuhi standar pembuktian formil dan materil. ${ }^{20}$ Namun tidak semua alat bukti yang telah memenuhi syarat formil dan materil memiliki nilai kekuatan pembuktian karena suatu alat bukti dapat memiliki nilai atau kekuatan pembuktian jika telah mendapat

19 Didasarkan Atas Surat Keterangan Kantor Urusan Agama No.B/Kua.09.03.08/Pw/4/2018, Tertanggal 13 April 2018

20 M.Natsir Asnawi, Op.Cit. hlm.33 
batas minimal pembuktian. ${ }^{21}$

Dalam perkara terkait keperdataan pengaturan mengenai jenis alat bukti telah ditentukan sebagaimana pasal $164 \mathrm{HIR} / 284 \mathrm{R} . \mathrm{Bg}$ dan pasal 1866 KUHPerdata. Disebutkan jenis alat bukti tersebut antara lain:22 (1) Alat bukti surat (tulisan); (2) Alat bukti saksi; (3) Persangkaan; (4) Pengakuan; (5) Sumpah.

Selain dari ketentuan tersebut, juga dikenal alat bukti pemeriksaan setempat (descente) yang diatur dalam pasal 153 HIR/180 R.Bg. dan pemeriksaan ahli (ekspertise) yang diatur dalam Pasal 154 HIR/181 R.Bg. Implementasi dari alat-alat bukti tersebut tunduk pada ketentuan-ketentuan yang diatur dalam HIR, R.Bg. maupun KUHPerdata.

Kekuatan pembuktian dari suatu alat bukti tergantung pada kekuatan pembuktian yang melakat dalam alat bukti. Kekuatan pembuktian pada alat bukti terbagi menjadi dua yaitu:23 (1) Kekuatan pembuktian intrinsik adalah kekuatan pembuktian yang lahir karena sifat alat bukti itu sendiri atau karena undang-undang menentukan demikian. Sebagai contoh alat bukti autentik yang memenuhi ketentuan pasal $165 \mathrm{HIR} / 284 \mathrm{R} . \mathrm{Bg}$ dan 1868 KUHPerdata yang menyatakan bahwa bukti autentik memiliki kekuatan pembuktian yang sempurna dan mengikat; (2) Kekuatan pembuktian ekstrinsik adalah kekuatan pembuktian yang dipengaruhi oleh suatu kondisi atau faktor diluar alat bukti itu sendiri. Kondisi dan faktor tersebut mempengaruhi kekuatan pembuktian suatu alat bukti. Sebagai contoh bukti akta autentik memiliki kekuatan pembuktian yang sempurna dan mengikat, tetapi jika akta autentik tersebut dapat dibantah kebenarannya maka kekuatan pembuktiannya turun menjadi bukti permulaan.

Dalam persoalan yang berkaitan dengan pembuktian keperdataan, alat bukti yang dijadikan sebagai dasar pembuktian yang paling utama adalah berupa tulisan. Karena memang tujuan membuat alat-alat bukti adalah dengan kemungkinan diperlukannya bukti-bukti itu dikemudian hari serta berguna dalam suatu pembuktian. ${ }^{24}$ Menurut Lilik Mulyadi alat bukti tertulis merupakan alat bukti pertama dan utama dalam sistem pembuktian di Indonesia. Dikatakan pertama karena alat bukti tertulis memiliki tingkat pertama atau tertinggi diantara bukti-bukti lain sedangkan pengutamaan alat bukti tertulis memang digunakan untuk kepentingan pembuktian. ${ }^{25}$

Dari alat-alat bukti tulisan ada suatu alat bukti yang sangat berharga untuk suatu pembuktian yaitu yang dinamakan akta. Akta sendiri merupakan suatu tulisan yang memang secara sengaja dibuat untuk dijadikan bukti tentang suatu peristiwa dan ditandatangani. Dengan demikian unsur terpenting dalam akta ialah kesengajaan untuk menciptakan suatu bukti tertulis dan penandatanganan tulisan itu. ${ }^{26}$

Diantara golongan surat-surat atau tulisantulisan yang dinamakan akta, terdapat satu golongan yang memiliki kekuatan pembuktian istimewa yaitu yang dinamakan akta otentik. Akta otentik merupakan suatu akta yang bentuknya telah ditentukan oleh undang-undang dan dibuat oleh pegawai umum yang berwenang untuk itu. Pegawai

21 Andul Manan, Penerapan Hukum Acara Perdata di Lingkungan Pengadilan Agama, Jakarta: Kencana 2006, hlm. 241

22 KUHPerdata, Pasal 1866

23 Natsir Asnawi, Op.Cit. hal 40

24 Subekti, Hukum Pembuktian, Jakarta: Pradnya Paramita, 2008, hlm.19

25 Lilik Mulyadi, Hukum Acara Perdata Menurut Teori Dan Praktek Peradilan Indonesia, Jakarta: Djambatan, 1998, hlm. 160

26 Ibid. hlm.25 
umum yang dimaksud adalah berlaku untuk seorang Notaris, Hakim, Juru Sita ataupun Pegawai Catatan Sipil dan sebagainya. Oleh karena itu akta-akta yang dibuat oleh pegawai umum sebagaimana disebutkan adalah merupakan akta-akta otentik. ${ }^{27}$

Dari uraiaan diatas dapat disimpulkan bahwa akta cerai dapat disebut sebagai akta otentik dikarenakan telah memenuh syarat-syarat dari akta otentik dalam fungsinya sebagai alat bukti yaitu antara lain dibuat dan dikeluarkan oleh pejabat pemerintah sesuai fungsi dan tugasnya serta di dalam akta tersebut juga memuat tanggal hari bulan dan tahun pembuatan serta ditandatangani oleh pejabat yang membuatnya. ${ }^{28}$

b. Kedudukan harta benda dalam perkawinan jika ditinjau dari kepemilikannya

Sebagaimana pasal 35 ayat $1 \mathrm{UU}$ Perkawinan yang mengatur ketentuan harta benda dalam perkawinan, telah disebutkan perbedaan harta bersama dan harta bawaan. Harta bersama (gono gini) adalah harta benda yang diperoleh selama masa perkawinan. Artinya, harta kekayaan yang diperoleh sebelum terjadinya perkawinan tidak disebut sebagai harta bersama. Hal tersebut juga ditegaskan dalam Pasal 1 huruf $\mathrm{f}$ Instruksi Presiden (Inpres) Nomor 1 Tahun 1991 tentang Kompilasi Hukum Islam yang menyatakan "harta bersama yaitu harta yang diperoleh baik sendiri-sendiri atau bersama suami-istri selama dalam ikatan perkawinan, tanpa mempersoalkan terdaftar atas nama siapapun". Dari uraiaan tersebut tentunya dapat ditarik suatu kesimpulan secara jelas terhadap perbedaan antara harta bersama (gono gini) dengan harta bawaan.
Kedudukan harta bersama maupun harta bawaan sangat juga ditentukan oleh peranan akta perkawinan maupun akta perceraiaan sebagai petunjuk. Hal tersebut tidak lain oleh karena akta perkawinan maupun perceraiaan memiliki fungsi dalam menentukan posisi dan kedudukan harta benda apakah merupakan masuk kedalam klasifikasi harta gono gini atau merupakan harta bawaan, jika ditunjau di status perkawinan pemilik pada saat harta benda itu diperoleh.

\section{Adanya keterkaitan antara status} kepemilikan harta benda dengan status perkawinan saat diperolehnya harta tersebut merupakan satu hal yang tidak dapat dipisahkan. Hal ini mengacu pada fungsi dari akta perkawinan maupun akta perceraiaan yang sebagaimana dijelaskan dalam Peraturan Presiden Nomor 25 Tahun 2008, bahwa fungsi dari diterbitkannya data kependudukan yang salah satunya berupa akta perkawinan maupun akta perceraiaan adalah bertujuan untuk memberikan keabsahan identitas dan kepastian hukum, perlindungan status hak sipil penduduk dan mendapatkan data mutktahir benar dan lengkap.

Salah satu unsur yang menjadi tujuan dari diterbitkannya akta cerai sebagai data kependudukan adalah adanya fungsi kepastian hukum terhadap status perkawinan seseorang sebagai duda/janda dan indikator adanya kepastian hukum di suatu negara itu sendiri adalah perundangan yang jelas dan perundangan tersebut diterapkan dengan baik oleh hakim dan petugas hukum lainnya. ${ }^{29}$ 
Kedudukan baik akta perkawinan maupun akta perceraiaan sebagai petunjuk dalam pembuktian status kepemilikan harta dapat dikatakan sangat penting dalam memberikan kejelasan dan kepastian hukum. Kepastian hukum tersebut adalah dalam hal memberikan bukti yang bertujuan untuk menegaskan guna menentukan siapa sajakah pihak-pihak yang sebenarnya memiliki kewenangan atau berhak terhadap suatu harta benda dan tentu saja pembuktian tersebut bertujuan untuk memberikan perlindungan terhadap pihak-pihak yang memang berhak atas kepemilikan harta benda itu sendiri.

Dalam prespektif hukum perdata segala sesuatu yang berhubungaan dengan harta benda atau harta kekayaan lazim disebut sebagai hak perdata. Hak perdata tersebut dapat dibagi dalam hak absolut (ius in re) dan hak relatif (ius ad rem). ${ }^{30}$ Hak Absolut adalah hak yang harus dihormati dan merupakan bagian dari keperdataan. ${ }^{31}$ Salah satu pengertian dari hak absolut adalah terkait dengan kebendaan atau disebut hak kebendaan sebagaimana yang diatur dalam Buku II KUHPerdata. Selain dari hak absolut terdapat juga hak keperdataan yang disebut sebagai hak relatif dan digolongkan sebagai hak perseorangan. ${ }^{32}$ Hak perseorangan dapat dikatakan erat hubungannya dengan hukum perikatan sebagaimana diatur dalam buku III KUHPerdata. Hak perseorangan merupakan hak yang timbul karena adanya hubungan perjanjian, undang-undang, dan lain-lain. ${ }^{33}$

Jika dibandingkan perbedaan antara hak kebendaan dengan hak perseorangan, maka dapat dilihat beberapa perbedaan antara keduanya yaitu: ${ }^{34}$

1. Hak kebedaan bersifat absolute atau dapat dipertahankan terhadap tuntutan setiap orang, sedangkan hak perseorangan bersifat relatif dan hanya dapat dipertahankan terhadap orang tertentu yaitu lawanya dalam suatu perjanjian;

2. Dalam hak kebendaan terhadap hubungan hukum secara langsung antara sesorang dengan suatu benda, sedangkan dalam hak perseorangan menimbulkan hubungan hukum antara dua orang atau lebih berkaitan dengan suatu benda atau suatu hal tertentu;

3. Hak kebendaan bersifat diutamakan atau didahulukan, sedangkan hak perseorangan mengenal asas kebersamaan atau keseimbangan hak;

4. Berkaitan dengan hak untuk memindahkan. Jika pada hak kebedaan pemindahan dapat dilakukan sepenuhnya namun pada hak perseorangan kemungkinan pemindahan hak adalah terbatas;

5. Dalam hak kebedaan dikenal berlakunya asas perlindungan sebagaimana diberikan pasal 1977 ayat (1) KUHPerdata yaitu orang yang secara jujur menguasai benda-benda bergerak dilindungi sedangkan pada hak perseorangan tidak dikenal asas perlindungan. ${ }^{35}$

Perbedaan antara hak kebendaan yang diatur dalam Buku II KUHPerdata dengan hak perseorangan yang diatur dalam Buku III KUHPerdata yaitu adalah menitikberatkan pada unsur-unsur bahwa hak kebendaan timbul oleh -

\footnotetext{
30 Rachmadi Usman, Hukum Kebendaan, Jakarta: Sinar Grafika, 2013, hlm. 105

31 Titik Triwulan Tutik, Hukum Perdata Dalam Sistem Hukum Nasional, Jakarta: Kencana Prenada Media Group, 2008, hlm. 153

32 Rachmadi Usman, Op.Cit. hlm. 106

33 lbid. hlm. 106

34 Ibid, hlm. 111

35 Frieda Husni Hasbullah, Hukum Kebendaan Perdata: Hak-hak yang member kenikmatan jilid 1, Jakarta: Ind-Hill Co, 2002, hlm. 5556
} 
karena telah ditetapkan oleh undang-undang yang berlaku sehingga seseorang memiliki hak dan kedudukan penuh atas benda tersebut sedangkan hak perseorangan timbul oleh karena didasarkan suatu perikatan atau kesepakatan baik berdasarkan perjanjian maupun undang-undang, sehingga hanya berlaku sebatas dari pelaksanaan perikatan tersebut. ${ }^{36}$

Dalam persoalan terkait harta benda dalam perkawinan, kedudukan dari harta benda perkawinan tersebut terkait hubungannya dengan hak kebendaan ataupun juga hak perseorangan tentunya hanya dapat dilihat apabila mencermati asal usul diperolehnya harta benda tersebut, sehingga untuk kemudian dapat dipastikan status dari harta benda tersebut terutama terhadap kepemilikannya.

Kedudukan seseorang yang sedang terikat dalam suatu perkawinan dapat dikatakan sebagai kedudukan yang sedang terikat dalam suatu perikatan, yang tentu saja perikatan tersebut melahirkan hak dan kewajiban. Difinisi dari perkawinan itu sendiri menurut pasal 1 UU Perkawinan adalah ikatan lahir batin antara seorang pria dan seorang wanita sebagai suami istri dengan tujuan membentuk keluarga atau rumah tangga yang bahagia dan kekal berdasarkan Ketuhanan Yang Maha Esa. Jadi perkawinan tersebut adalah ikatan seorang pria dan wanita berarti perkawinan sama dengan perikatan. ${ }^{37}$

Hubungan perikatan yang bernama perkawinan tentunya juga menimbulkan keterikatan dengan harta benda yang diperoleh selama perkawinan berlangsung. Seperti yang telah diuraikan dalam pasal 35 ayat 1 UU Perkawinan disebutkan bahwa harta benda yang diperoleh selama perkawinan menjadi harta bersama. Kemudian dilanjutkan pada pasal 36 ayat $1 \mathrm{UU}$ Perkawinan yang menyebutkan bahwa mengenai harta bersama, suami atau istri dapat bertindak atas persetujuan kedua belah pihak.

Ketentuan yang didasari pasal 35 ayat 1 dan pasal 36 ayat 1 UU Perkawinan menunjukan bahwa harta benda yang diperoleh dalam perkawinan dapat dikatakan sebagai kelompok dari harta kekayaan yang masuk golongan hak perseorangan, hal ini dikarenakan adanya konsep kepemilikan atas harta benda tersebut yang didasarkan oleh suatu perikatan bernama perkawinan, yang tentunya hal tersebut menimbulkan adanya kepemilikan bersama terhadap harta benda tersebut serta perlu adanya persetujuan dari masing-masing pihak yang terlibat dalam perkawinan ketika harta benda tersebut akan dibebani suatu perbuatan hukum berupa apapun.

Berdasarkan pasal 35 ayat 1 UU Perkawinan kedudukan harta benda yang diperoleh selama perkawinan tentunya berbeda dengan kedudukan harta benda yang diperoleh sebelum terjadinya perkawinan atau harta benda yang memang diperoleh ketika seseorang tidak lagi terikat suatu hubungan perkawinan baik yang disebabkan oleh kematian, perceraiaan ataupun penetapan pengadilan. Status harta benda tersebut dikenal dengan sebutan sebagai harta bawaan.

Sifat dari kedudukan harta bawaan yaitu memberikan kewenangan penuh kepada pemiliknya untuk melakukan perbuatan hukum terhadap harta bendanya tanpa memerlukan adanya persetujuan dari siapapun termasuk dari pasangan kawinnya. 
Dari pemahaman tersebut dapat dipersamakan bahwa harta bawaan memiliki kesesuaiaan hubungan dengan hak kebendaan sebagai bagian dari harta kekayaan. Kesesuaiaan tersebut timbul dan terletak pada kesamaan sifat kepemilikannya. Hal ini dapat dilihat dari pengertian sifat hak kebendaan itu sendiri jika dipersamakan dengan sifat harta bawaan. Menurut Sri Soedewi Masjchoen Sofwan, hak kebendaan merupakan hak mutlak atas suatu benda dan dapat memberikan kekuasaan atau kewenangan langsung atas benda tersebut dan dapat dipertahankan dari siapapun. ${ }^{38}$

Sebagaimana yang telah diuraikan sebelumnya perbedaan antara harta bawaan dengan harta yang diperoleh selama perkawinan atau gono gini terletak pada kewenangan sesorang dalam kedudukannya selaku pemilik atas harta benda tersebut sebagaimana diartikan dalam hak kebendaan atau perseorangan. Kedudukan tersebut sangat penting untuk menentukan apakah orang tersebut memang berwenang secara penuh terhadap harta benda yang dimilikinya tanpa adanya hak dari orang lain didalamnya atau justru sebaliknya harta benda tersebut memang merupakan suatu bentuk aset yang didalamnya terdapat hak orang lain seperti hak pasangan kawinya meskipun harta benda tersebut hanya terdaftar atas nama salah satu pihak.

Peranan dari akta perkawinan maupun akta cerai memegang fungsi sebagai dasar petunjuk dalam menentukan status dan kedudukan atas kepemilikan harta benda, apakah masuk kedalam harta gono gini atau harta bawaan. Ketiadaan suatu petunjuk atas status harta tentunya menyebabkan sulitnya untuk dilakukan pembuktian apakah harta benda tersebut masuk sebagai harta bawaan atau harta gono gini. Karena pembuktian tersebut penting untuk menentukan pihak-pihak manakah yang memang benar-benar memiliki hak serta memang wajib dimintai persetujuan ketika harta benda yang dimaksud akan dibebani suatu perbuatan hukum tertentu.

Pada Putusan Pengadilan Negeri Surakarta Nomor 20/pdt.G/2013/PN.Ska tercermin suatu permasalahan hukum yang timbul oleh karena disebabkan kurangnya pihak yang seharusnya dihadirkan untuk dimintakan persetujuannya. Kasus yang terjadi yaitu dibatalkannya Akta Jual Beli atas tanah dan/atau bangunan yang dibuat dihadapan Sunarto, Sarjana Hukum, selaku Notaris/PPAT Kota Surakarta oleh Pengadilan Negeri Surakarta. Pembatalan tersebut terjadi tidak lain oleh karena jual beli yang dilaksanakan para pihak tidak melibatkan mantan istri dari pihak penjual. Pihak Notaris/PPAT menyatakan pada saat transaksi jual beli berlangsung penjual hanya menghadirkan istri keduanya yang namanya sebagaimana tertera dalam Kartu Keluarga sebagai satu-satunya dasar tertulis yang menjadi acuan untuk menguatkan keterangan dari pihak penjual itu sendiri, tanpa mengetahui bahwa harta tanah yang akan dijadikan objek peralihan memiliki keterkaitan hak dengan mantan istri dari pihak penjual yang mana seharusnya dihadirkan untuk dimintai persetujuannya. Kasus pembatalan akta jual beli tersebut merupakan contoh dari konsekuensi hukum yang timbul dari ketiadaan data pentunjuk yang bernama akta cerai maupun putusannya yang berakibat pada sulitnya dilakukan pembuktian atas status kepemilikan harta.

38 Rachmadi Usman, Op.Cit. hlm.109 
Terkait kasus diatas fungsi dari pembuktian atas status kepemilikan harta benda sangat penting untuk menentukan pihak-pihak yang berhak atas harta benda itu sendiri. Artinya status kepemilikan atas harta benda tidak hanya dapat disandarkan atas ucapan atau keterangan seseorang, harus ada bukti yang dapat mendukung kebenaran upacan atau keterangan tersebut, dalam permasalahan ini bukti akurat yang dapat dijadikan dasar adalah bukti tertulis yang bernama akta cerai ataupun putusannya. Pentingnya untuk dapat dibuktikannya status harta benda terkait ada tidaknya pihak lain yang berhak atas harta benda tersebut mengacu sebagaimana ditentukan dalam pasal 1865 KUHPerdata mengatur tentang pembuktian, disebutkan bahwa setiap orang yang mengendalikan bahwa ia mempunyai sesuatu hak, atau, guna meneguhkan adanya haknya sendiri ataupun membantah adanya hak dari orang lain, menunjuk pada adanya suatu peristiwa, maka diwajibkan untuk membuktikan adanya hak atau peristiwa tersebut.

Akta cerai sebagai alat otentik memang memiliki kekuatan pembuktian sempurna sebagai dasar putusnya hubungan perkawinan seseorang. Kekuatan pembuktian sempurna lebih mengacu pada nilai pembuktian itu sendiri. Artinya alat bukti tersebut tidak memerlukan alat bukti lainnya untuk membuktikan suatu peristiwa, hubungan hukum serta hak dan kewajiban. ${ }^{39}$

Ketiadaan akta cerai karena penarikannya oleh KUA sebagai syarat menikah lagi tentunya menghapus kepastian hukum terhadap status perkawinan sebagai duda/janda yang pernah dialami seseorang. Persoalan tersebut juga berdampak pada tidak adanya kepastian hukum dalam hal pembuktian status harta bendanya, apakah harta benda tersebut masuk kedalam harta bawaan yang diperoleh selama menyadang status duda/janda atau memang masuk kedalam lingkupan harta gono gini dengan mantan suami atau istri yang memang belum terbagi setelah perceraiaan. Karena tujuan utama suatu pembuktian dalam pemeriksaan perkara perdata adalah untuk mengambil atau menjatuhkan putusan yang bersifat difinitif, pasti dan memiliki akibat hukum. ${ }^{40}$

\section{Penutup}

\subsection{Kesimpulan}

KUA dalam memberlakukan persyaratan penarikan akta cerai berikut putusannya bagi pasangan yang pernah bercerai untuk melangsungkan kembali suatu perkawinan telah menyebabkan sulitnya dilakukan pembuktian atas status perkawinan seseorang sebagai duda/janda pada saat diperolehnya harta benda/harta kekayaan. Hal tersebut berdampak pada tidak memilikinya kepastian hukum terhadap status harta benda apakah harta benda tersebut masuk kedalam klasifikasi harta bawaan yang diperoleh setelah terjadinya perceraiaan dan sebelum dilangsungkanya perkawinan yang kedua/lebih atau memang harta benda tersebut merupakan harta gono gini yang diperoleh dari perkawinannya terdahulu dan belum terbagi setelah terjadinya perceraiaan.

\subsection{Saran}

Penarikan Akta Cerai berikut putusannya oleh KUA seharusnya diikuti dengan adanya solusi 
konkret yaitu mencantumkan didalam akta nikah penyebab dan kapan perkawinan seseorang tersebut dinyatakan telah terputus. Persyaratan penarikan Akta Cerai berikut putusannya oleh KUA bagi pasangan yang telah bercerai untuk kembali melangsungkan perkawinan tentunya telah menghapus suatu alat bukti yang dapat menerangkan dan menjelaskan telah terjadinya suatu peristiwa penting yang terjadi pada seseorang yang bernama perceraiaan. Oleh karena itu pentingnya mensertakan penyebab dan kapan perkawinan seseorang tersebut dinyatakan telah terputus, terutama yang disebabkan oleh perceraiaan menjadi sangatlah penting mengingat data tersebut merupakan

\begin{abstract}
data pengganti dari Akta Cerai maupun putusannya sebagai dasar acuan yang memberikan kepastian hukum dalam menentukan status kepemilikan harta benda yang diperoleh sebelum terjadinya perkawinan yang kedua/lebih, apakah harta benda tersebut memang merupakan harta bawaan yang diperoleh selama bercerai atau merupakan harta gono gini yang masih memiliki keterkaitan hak dengan mantan suami/istrinya terdahulu, sehingga dalam melakukan perbuatan hukum apapun atas harta benda tersebut wajib dimintakan persetujuan dari mantan suami/istrinya tersebut.
\end{abstract}

\section{DAFTAR PUSTAKA}

\section{Buku}

Asnawi, M Natsir. Hukum Pembuktian Perkara Perdata Di Indonesia. Yogyakarta: UII Press, 2013.

Budiono, Abdul Rachmad. Pengantar IImu Hukum. Malang: Bayumedia Publishing , 2005.

Hadikusuma, Hilman. Hukum Perkawinan Indonesia,. Bandung: Mandar Maju, 2002.

Hasbullah, Frieda Husni. Hukum Kebendaan Perdata:Hak-hak yang member kenikmatan jilid 1. Jakarta: Ind-Hill Co, 2002.

HR, A Damanhuri. Segi-segi Hukum Perjanjian Perkawinan Harta Bersama. Bandung: CV Mandar Maju, 2007.

Manan, Andul. Penerapan Hukum Acara Perdata di Lingkungan Pengadilan Agama. Jakarta: Kencana, 2006.

Mertukusumo, Sudikno. Hukum Acara Perdata Indonesia. Yogyakarta: Universitas Admajaya, 2010.
Mulyadi, Lilik. Hukum Acara Perdata Menurut Teori Dan Praktek Peradilan Indonesia. Jakarta: Djambatan, 1998.

Subekti. Hukum Pembuktian. Jakarta: Pradnya Paramita, 2008.

Tutik, Titik Triwulan. Hukum Perdata Dalam Sistem Hukum Nasional. Jakarta: Kencana Prenada Media Group, 2008.

Usman, Rachmadi. Hukum Kebendaan. Jakarta: Sinar Grafika, 2013.

\section{Internet}

"Fungsi Pencatatan Perkawinan" https://www.researchgate.net/publication/ 42323389 Fungsi PencatatanPerkawinan MenurutUndang-Undang Nomor 1 Tahun 1974 studi kasus pengadilan agama Medan, diakses pada tanggal 30 Januari 2018

"Pembagian harta gono gini dalam perceraiaan" https://kantorpengacara.co/prosedur- 
144 Robby Pramono dkk, Konsekuensi Yuridis Dari Ketiadaan Akta Cerai....

pembagian-harta-gono-gini-dalamperceraian / diakses pada 01 Februari 2018

\section{Peraturan Perundang-undangan}

Kitab Undang-Undang Hukum Perdata (KUH

Undang-Undang Nomor 1 Tahun 1974 Tentang perkawinan (Lembaran Negara Republik Indonesia Nomor 1 Tahun 1974 Tambahan Berita Negara Republik Indonesia Nomor 3019)

Undang-Undang Nomor 7 Tahun 1989 Tentang Pengadilan Agama (Lembaran Negara Tahun 1989 Nomor 49 Tambahan Lembaran Negara Republik Indonesia Nomor 3400)

Undang-Undang Nomor 24 Tahun 2013 sebagai perubahan dari tentang Undang-Undang Nomor 23 Tahun 2006 tentang Administrasi Kependudukan (Lembaran Negara Tahun
2013 Nomor 232 Tambahan Lembaran Negara Republik Indonesia Nomor 5475)

Peraturan Pemerintah Nomor 9 Tahun 1975 Tentang Pelaksana Undang-Undang Nomor 1 Tahun 1974 Tentang perkawinan

Peraturan Presiden Nomor 1 Tahun 1991 Tentang Kompilasi Hukum Islam

Peraturan Presiden Nomor 25 Tahun 2008, Tentang Persyaratan Pendaftaran Penduduk Dan Catatan Sipil

\section{Putusan}

Putusan Pengadilan Negeri Surakarta Nomor 20/pdt.G/2013/PN.Ska

Surat Keterangan Kantor Urusan Agama No.B/Kua.09.03.08/Pw/4/2018, Tertanggal 13 April 2018 